\title{
Eastern Redcedar Seed Source Test in Western Kansas
}

\author{
Wayne A. Geyer, Keith D. Lynch, and Charles J. Barden
}

\begin{abstract}
Sources of eastern redcedar (Juniperus virginiana L.) were established as a provenance test near Colby, Kansas, U.S. in 1980. Height, diameter, number of stems, crown density, branch angle, and general vigor were evaluated with ANOVA, cluster analysis, simple correlation, and regression analysis techniques. Clear source and cluster differences were found. Total height at 23 years ranged from 3.6 to $5.4 \mathrm{~m}$ (11.8 to $17.7 \mathrm{ft}$ ), dbh (diameter at breast height) ranged from 2.5 to $14.4 \mathrm{~cm}$ ( 1 to $5.7 \mathrm{in}$ ), and mean survival rate was $78 \%$. Sources from the central plains grew best. Selection of fast-growing sources may begin at five years after field planting. Key Words. Growth Characteristics; Juniperus virginiana L.; Juniperus scopulorum; Seed Sources.
\end{abstract}

Eastern redcedar (Juniperus virginiana L.) is the most widely distributed conifer tree in the eastern United States (Burns and Honkaka 1990). The species range extends into southern Canada, and has been naturalized into the western Great Plains by natural regeneration from planted trees. Eastern redcedar is a small- to medium-sized, slow-growing intolerant tree (Harlow et al. 1979). There have been numerous taxonomical studies on this tree (Fassett 1944; Comer et al 1982; Adams 1983; Schaefer 1995). Cunningham and King (2000) identified genetic variation of various major traits for 10-year-old plantings, and seed source selection zones, for the Great Plains area.

This test is a part of a larger regional study initiated in 1973 by the now disbanded Technical Committee of the Great Plains Agricultural Council. The objectives were to determine the genetic variation of major traits and to identify the best sources of seed for windbreak applications. This paper presents the portion of the study established in Colby, Kansas after 23 years of growth in the field.

\section{MATERIALS AND METHODS}

A complete description of the methodology used for this greater study can be found in Van Haverbeke and King (1990). Seed cones were collected from 140 trees in natural stands and windbreaks across the Great Plains. Seed trees that had desirable windbreak characteristics (e.g., abundant branches, dense foliage) were selected. Seed lots were sown in the USDA Forest Service Bessey Nursery near Halsey, Nebraska in 1977 and were out-planted at 12 test sites in 1980 . This study reports on the Colby site $\left(39.38^{\circ} \mathrm{N}\right.$ and $\left.101.07^{\circ} \mathrm{W}\right)$, located in the central geographic region of zones established by Van Haverbeke (1968). Soil is from the Keith series loam (e.g., fine-silty, mixed, mesic Aridic Haplustolls) and Richfield silty clay loam (e.g., fine, montmorillonitic, mesic Aridic Haplustolls). A randomized completeblock with five replications of 4-tree, linear plots was established having 20 trees maximum for each source. A total of 2320 trees were planted, along with 520 Rocky Mountain juniper (Juniperus

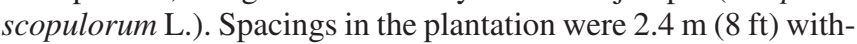

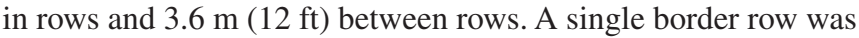
planted on all sides. Clean cultivation was maintained for five years. Growth evaluations were made at age 5, 10, and 23 years.
Statistical analyses were performed with SAS software (Statistical Analysis System, SAS Institute Inc., Cary, NC). Data were analyzed via the analysis of variance procedure, and the Duncan's means test was used for mean separation. Cluster analysis (Ward's minimum variance) were used to identify seed sources with similar performance characteristics. Variables usse in said analyses were survival rate, total height, dbh (diameter at breast height), number of stems, crown density, branch angle, vigor, latitude, longitude, and elevation.

If trees had multiple stems, then only the largest was evaluated for height and diameter. Simple Pearson correlations were computed among seed sources of individual trees for each trait. The correlation of each trait with latitude and longitude was also examined. Least squares regression models of differences in latitude, longitude, and elevation between source locations and the Colby plantation were run to find the extent of the geographic area from which seed may be collected to give good tree growth performance in western Kansas. To determine the reliability of early seed source selection, age/age correlations were computed for survival and height of source means at age 10 and age 23 .

\section{RESULTS}

Significant differences among seed sources existed for survival, height, dbh, number of stems, crown density, branch angle, and vigor. Each is discussed separately, but we also chose to identify more general patterns of variation by using cluster analysis.

\section{Survival}

Seed sources were significantly different at $P<0.01$ (analysis of variance) in survival rates through age 23 , with a range of 10 to $100 \%$. The mean survival was $78 \%$. The best sources were from the central part of the range, while the poorest surviving sources were from southern Texas which was $30 \%$.

\section{Height}

Seed sources were significantly different in height at the $P<0.01$ (analysis of variance) through age 23 (Table 1). The mean height for all of the trees was $5.3 \mathrm{~m}(17.5 \mathrm{ft})$, ranging from 3.1 to $6.2 \mathrm{~m}$ 
Table 1. Survival, height, and dbh rankings of top and bottom 10 eastern redcedar seed sources at 23 years.

\begin{tabular}{|c|c|c|c|c|}
\hline $\begin{array}{c}\text { Source } \\
\# \\
\end{array}$ & State & $\begin{array}{l}\text { Survival } \\
(\%)\end{array}$ & $\begin{array}{l}\text { Height } \\
\mathrm{m}(\mathrm{ft})\end{array}$ & $\begin{array}{l}\text { Dbh } \\
\mathrm{cm} \text { (in) }\end{array}$ \\
\hline \multicolumn{5}{|c|}{ Top 10 Sources } \\
\hline 7514 & Nebraska & $100 \mathrm{a}^{2}$ & $6.2(20.3) \mathrm{a}^{\mathrm{z}}$ & $13.2(5.2) \mathrm{a}^{2}$ \\
\hline 5334 & South Dakota & $100 \mathrm{a}$ & $6.2(20.2) \mathrm{a}$ & $12.7(5.0) \mathrm{a}$ \\
\hline 7315 & Kansas & $100 \mathrm{a}$ & $6.2(20.2) \mathrm{a}$ & $13.7(5.4) \mathrm{a}$ \\
\hline 7522 & Kansas & $100 \mathrm{a}$ & $6.2(20.2) \mathrm{a}$ & $13.7(5.4) \mathrm{a}$ \\
\hline 10235 & Nebraska & $100 \mathrm{a}$ & $6.1(20.0) \mathrm{a}$ & $13.5(5.4) \mathrm{a}$ \\
\hline 10722 & Iowa & 95 a & $6.1(20.0) \mathrm{a}$ & $13.0(5.1) \mathrm{a}$ \\
\hline 6315 & South Dakota & $85 \mathrm{a}$ & $6.1(19.9) \mathrm{a}$ & $13.0(5.1) \mathrm{a}$ \\
\hline 7515 & Nebraska & $100 \mathrm{a}$ & $6.1(19.7) \mathrm{a}$ & $12.7(5.0) \mathrm{a}$ \\
\hline 10713 & Iowa & $90 \mathrm{a}$ & $6.0(19.7) \mathrm{a}$ & $14.0(5.5) \mathrm{a}$ \\
\hline 10213 & South Dakota & $85 \mathrm{a}$ & $6.0(19.6) \mathrm{a}$ & $12.7(5.0)$ \\
\hline Mean & & 94 & $6.1(19.9)$ & $13.2(5.2)$ \\
\hline \multicolumn{5}{|c|}{120 other central sources } \\
\hline Mean & & 85 & $5.4(17.6)$ & $11.2(4.4)$ \\
\hline \multicolumn{5}{|c|}{ Bottom 10 sources } \\
\hline 8613 & Texas & $60 \mathrm{a}$ & $4.0(13.1) \mathrm{a}$ & $6.6(2.6)$ fghi \\
\hline 8514 & Texas & $60 \mathrm{a}$ & $3.9(12.8) \mathrm{a}$ & 6.6 (2.6) fghi \\
\hline 8623 & Texas & $45 \mathrm{a}$ & $3.8(12.6) \mathrm{a}$ & $5.6(2.2)$ fghi \\
\hline 8625 & Texas & $30 \mathrm{a}$ & $3.7(12.2) \mathrm{ab}$ & $1.2(3.2) \mathrm{jk}$ \\
\hline 8615 & Texas & $45 \mathrm{a}$ & $3.6(12.0) \mathrm{ab}$ & $5.3(2.1) \mathrm{hj}$ \\
\hline 13321 & Texas & $20 \mathrm{a}$ & $3.6(12.0) \mathrm{ab}$ & 6.3 (2.5) fghi \\
\hline 8612 & Texas & $40 \mathrm{a}$ & 3.5 (11.6) ab & 5.6 (2.2) fghij \\
\hline 8714 & Texas & $30 \mathrm{a}$ & 3.5 (11.6) ab & $4.3(1.7) \mathrm{jk}$ \\
\hline 13323 & Texas & $10 \mathrm{a}$ & $3.2(10.5) \mathrm{ab}$ & $2.5(1.0) \mathrm{k}$ \\
\hline 13324 & Texas & $40 \mathrm{a}$ & $3.1(10.1) a b$ & $4.1(1.6) \mathrm{jk}$ \\
\hline Mean & & 38 & $3.6(11.8)$ & $5.6(2.2)$ \\
\hline Mean & All 140 & 78 & $5.3(17.5)$ & $10.9(4.3)$ \\
\hline
\end{tabular}

${ }^{2}$ Letters indicate significance differences.

(10.2 to $20.3 \mathrm{ft}$ ). Specific patterns were found geographically for total height. The tallest trees (10) had high survival (100\%) and were also generally in the upper $10 \%$ of dbh [12.9 cm (5.1 in)]. The shortest $10 \%$ of the sources were from Texas [4.2 $\mathrm{m}(13.9 \mathrm{ft})]$.

\section{Diameter}

Seed sources (Table 1) were significantly different at the $P<0.01$ (analysis of variance). The mean dbh was $10.9 \mathrm{~cm}$ (4.3 in) with a range of 2.5 to $14.5 \mathrm{~cm}$ (5.7 in). Specific patterns were found, geographically, for diameter measurements. The largest diameter trees were from Iowa [14 cm (5.5 in)]. Sources from the central plains were generally the largest; mean survival was approximately $85 \%$.

\section{Other Variables}

The mean value of the number of stems per tree for the entire planting was 1.6 , with a range of 1 to 3.3 stems per tree. Nearly $15 \%$ of the sources showed a consistent trend toward a single-stem habit. No geographic pattern was recognized. Crown density was good for most sources planted, with ratings ranging from medium to dense for windbreak characteristics. However, Southern Texas sources were found to have sparse to very sparse crowns. Over $90 \%$ of the sources had branch angles between 45 and $90^{\circ}$. All sources had good vigor and were generally healthy showing minimal crown damage.

\section{Cluster Analysis}

Cluster analysis included all 140 sources. The analysis differentiated 3, 4, and 5 clusters for height, with a significance that was $P<0.01$ for height, survival, and dbh. The other variables listed were deleted in the analysis because of similar values. General patterns of variation were identified by using this analysis. Distinct geographic patterns were shown in the all of the clusters evaluated. The 5-cluster analysis was selected as it most clearly indicated geographic source patterns of variation (Figure 1). A similar arrangement was found in South Dakota for 10-year-old eastern redcedar (Schaefer 1995), with the exception that Texas sources were not considered. Cluster values are shown in Table 2. The height values for first through fifth clusters were $5.8,5.4,4.9,4.2$, and $3.5 \mathrm{~m}(18.9,17.6,16.1,13.9$, and $11.4 \mathrm{ft})$, dbh values were $13,11.7,9.7,7.4$, and $4.6 \mathrm{~cm}(5.1,4.6$, $3.8,2.9$, and 1.8 in ). The two Texas sources were the shortest.

\section{Correlations}

Age/age correlations between height and dbh, were particularly high. Height growth at 5 years (Table 3 ) predicted the tallest trees at 10 years (Pearson correlation coefficient $=0.960$ ). Height at 10 years (Table 3 ) predicted height at 23 years $(0.945)$. Five-year data was not available for determining 23-year relationships, but one could assume that the correlations would be high. The tallest trees had the largest diameters (correlation $=0.930$ ). The other major variables and the geographic traits did not provide any significantly high correlations to predict growth (Table 3).

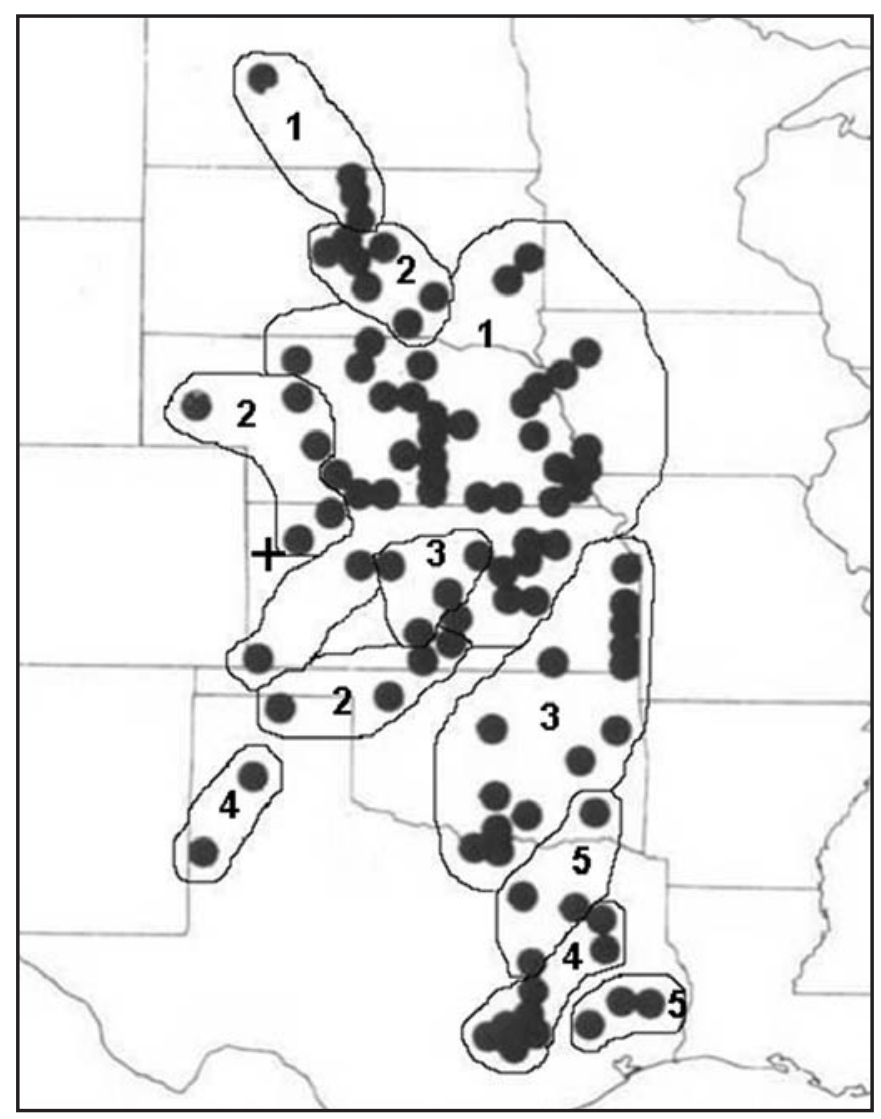

Figure 1. Performance clusters of eastern redcedar seed sources representing natural stands based upon Ward's method. The plus sign indicates the location of test plantation. 
Table 2. Mean growth values of 5 ERC clusters

\begin{tabular}{|c|c|c|c|c|c|c|c|c|}
\hline Cluster & Geography & $\begin{array}{l}\text { Height } \\
\mathrm{m}(\mathrm{ft})\end{array}$ & $\begin{array}{l}\text { Survival } \\
(\%)\end{array}$ & $\begin{array}{l}\text { Dbh } \\
\mathrm{cm} \text { (in) }\end{array}$ & $\begin{array}{l}\text { Density } \\
--\end{array}$ & $\begin{array}{l}\text { \# stems } \\
--\end{array}$ & $\begin{array}{l}\text { Branch y } \\
--\end{array}$ & $\begin{array}{l}\text { Vigor }^{x} \\
-- \\
\end{array}$ \\
\hline 1 & Eastern NE & $5.8(18.9) \mathrm{a}$ & $100 \mathrm{a}$ & $13.0(5.1) \mathrm{a}$ & $4.1 \mathrm{a}$ & $1.5 \mathrm{c}$ & $2.0 \mathrm{a}$ & $4.9 \mathrm{a}$ \\
\hline 2 & $\begin{array}{l}\text { Scattered } \\
\text { NE, KS, } \\
\text { OK }\end{array}$ & $5.4(17.6) \mathrm{b}$ & $100 \mathrm{a}$ & $11.7(4.6) b$ & $3.9 \mathrm{a}$ & $1.6 \mathrm{c}$ & $1.9 \mathrm{a}$ & $4.9 \mathrm{a}$ \\
\hline 3 & $\begin{array}{l}\text { SE \& central } \\
\text { KS }\end{array}$ & $4.9(16.1) \mathrm{c}$ & $100 \mathrm{a}$ & $9.7(3.8) b$ & $3.6 \mathrm{~b}$ & $2.0 \mathrm{a}$ & $1.9 \mathrm{a}$ & $4.7 \mathrm{~b}$ \\
\hline 4 & South. OK \& & & & & & & & \\
\hline 5 & SE TX & $3.5(11.4) \mathrm{d}$ & $99 \mathrm{ab}$ & $4.6(1.8) \mathrm{c}$ & $2.6 \mathrm{c}$ & $1.7 \mathrm{ab}$ & $2.0 \mathrm{a}$ & $3.9 \mathrm{c}$ \\
\hline Prob. $(\%)$ & -- & $<1$ & $<1$ & $<1$ & $<1$ & $<1$ & 9 & $<1$ \\
\hline
\end{tabular}

$\mathrm{z} 1=$ very sparse $; 2=$ sparse $3=$ medium $; 4=$ dense $; 5=$ dense

${ }^{\mathrm{y}} 1=<45$ deg. angle; $2=45$ to 89 deg.; $3=>90$ deg.

${ }^{\mathrm{x}} 1=$ dead $; 2=$ barely alive; $3=$ moderate $4=$ slight damage; $5=$ healthy.

Table 3. Correlations of height and dbh of eastern red cedar with age and geographic traits.

\begin{tabular}{lllllll}
\hline & $\begin{array}{l}\text { Height @ } \\
10 \text { yrs. }\end{array}$ & $\begin{array}{l}\text { Height @ } \\
\text { 3 yrs. }\end{array}$ & $\begin{array}{l}\text { Dbh @ } \\
\text { 23 yrs. }\end{array}$ & Long. & Lat. & Elev. \\
\hline $\begin{array}{c}\text { Height } \\
5 \text { yrs. }\end{array}$ & $0.960^{z}$ & & & & & \\
10 yrs. & & 0.945 & 0.912 & 0.584 & 0.298 & 0.515 \\
23 yrs. & & 0.931 & 0.338 & 0.283 & 0.416 \\
& & & & & \\
Dbh 23 yrs. & 0.931 & & 0.592 & 0.286 & 0.463 \\
\hline
\end{tabular}

${ }^{\mathrm{z}}$ Approximate value from Cunningham and King (2000).

\section{Regression Analysis}

The reliability of the regression model to predict the 23-year height from the 10-year height data gave an Rsquare value of 0.8939 and was significant at the $1 \%$ level.

The regression model to predict 23-year old growth and survival using a combination of geographic variables as differences from the Colby plantation gave R-square values of 0.6426 (height), 0.6404 (dbh), and 0.4435 (survival) for values significant at the $1 \%$ level. Sources north and east of the Colby plantation produced taller and larger diameter trees with higher survival.

\section{DISCUSSION AND CONCLUSIONS}

In an earlier study comparing eastern redcedar to Rocky Mountain juniper in the Great Plains Region (Cunningham and King 2000), tree survival did not differ significantly. Eastern redcedar were taller, and had wider crowns than did Rocky Mountain juniper at 10 years of age, but Rocky Mountain juniper has better crown density for wind reduction than redcedar.

Our findings showed growth at 10 years predicted superior growth at 23 years, and in agreement with our previously reported study for Rocky mountain juniper (Geyer et al. 2007), Schafer (1995) and Van Haverbeke and King (1990), for five-year and ten-year relationships.

In our Kansas study, we identified at 23 years of age the best area to collect eastern redcedar seed for production of seedlings for Kansas was from an area bounded by eastern and central Nebraska, central and northern Kansas, and south eastern South Dakota. Two southern clusters from southern Oklahoma and eastern Texas were much shorter in height. Trees from these sources are not recommended for windbreak plantings in western Kansas.
Thus, the general good health, dense crown, and many stems of eastern redcedar from the preferred sources would provide excellent structure, and this species should be selected for use in establishing new windbreaks in western Kansas and nearby areas in central and western Nebraska. This study suggests use of a seed source from within $482.8 \mathrm{~km}$ (300 mi) of the planting site would provide the best results for windbreak plantings in the Great Plains.

\section{LITERATURE CITED}

Adams, R.P. 1983. Intraspecific terpenoid variation in J. Scopulorum: Evidence for Pleistocene refugia and recoloniation in western North America, Taxon 32:30-46.

Burns, R.M., and B.H. Honkala. 1990. USDA Forest Service. Agriculture Handbook 654. Washington D. C. 675 pp.

Comer, C., R.P. Adams, and D.F. Van Haverbeke. 1982. Intra- and interspecific variation Juniperus virginia and J. scopulorum seedlings based on volatile oil composition. Biochemical Systemics and Ecology 10:179-306.

Cunningham, R.A., and R.M. King. 2000. Juniper seed sources in the Great Plains. General Technical Report, RMRS-GTR-51. USDA Forest Service, Rocky Mountain Forest Experiment Station. Fort Collins, CO.

Fassett, N.C. 1944. Juniperus virginia, J. horizontalis, and J. scopulorum - II. Hybrid swarms of Juniperus virginia and Juniperus scopulorum. Bulletin of the Torrey Botanical Club 71: 475-483.

Geyer, W.A., K.D. Lunch, and C.J. Barden. 2007. Rocky Mountain juniper seed source test in western Kansas, U.S. Arboriculture \& Urban Forestry 33(5): 325-328.

Harlow, W.M., E.S. Harrar, and E.S. White. 1979. Textbook of Dendrology, 6th Edition, McGraw Hill Book Co., Inc. New York, 510 pp.

SAS. 2000. SAS User's Guide. Version 8.1. Gary, NC. SAS Institute Inc. 1696 p. Schaefer, P. 1995. Ten-year results of an eastern redcedar and Rocky Mountain juniper provenance test in eastern South Dakota. Northern Journal of Applied Forestry 12(1): 30-35.

Van Haverbeke, D.F. 1968. A population analysis of Juniperus in the Missouri River Basin. New Series 38. Lincoln, NE, University of Nebraska Studies. 82pp.

Van Haverbeke, D.F., and R.M. King. 1990. Genetic variation in the Great Plains Juniperus. USDA Forest Service. Research Paper M-292. Lincoln, NE. 8pp.

Acknowledgements. This is contribution no. 08-397-J from the Kansas Agricultural Experiment Station, Manhattan, Kansas. 
Wayne A. Geyer (corresponding author)

Professor

Forestry Division

Throckmorton Hall

Kansas State University

Manhattan, KS 66506, U.S.

Wgeyer@ksu.edu

Keith D. Lynch

Associate Professor

Forestry Division

Throckmorton Hall

Kansas State University

Manhattan, KS 66506, U.S.

Charles J. Barden

Associate Professor

Forestry Division

Throckmorton Hall

Kansas State University

Manhattan KS, 66506, U.S.
Résumé. Les sources de genévrier de Virginie (Juniperus virginiana L.) ont été plantées pour les fins d'une expérience de test de provenance près de Colby au Kentucky en 1980. La hauteur, le diamètre, le nombre de tiges, la densité de la cime, l'angle des branches et la vigueur générale ont été évalués au moyen de techniques d'analyse de variances, d'analyse de grappes, de simple corrélation et d'analyse de régression. Des différences entre chaque source et les groupes ont été découvertes. La hauteur totale à 23 ans variait de 3,6 à $5,4 \mathrm{~m}$, le D.H.P. de 2,5 à $14,4 \mathrm{~cm}$ et le taux de survie était de $78 \%$. Les sources provenant des Plaines centrales étaient les meilleures pour leur croissance. La sélection de sources à croissance rapide peut débuter à compter de la cinquième année après la plantation en champ.

Zusammenfassung. 1980 wurden in der Nähe von Colby, Kansas Quellen für Rotzedern als ein Herkunftstest etabliert. Mit ANOVA, Cluster-Analyse, einfacher Korrelation und Regressionsanalysetechniken wurde die Höhe, Durchmesser, Anzahl der Stämme, Kronendichte, Astwinkel und allgemeine Vitalität bewertet. Es wurden klare Clusterund Herkunftsunterschiede gefunden. Die totale Höhe im Alter von 23 rangierte von 3,6 bis 5,4 m, BHD von 2,5 bis $14,4 \mathrm{~cm}$ und die durchschnittliche Überlebensrate betrug 78\%. Die Bäume aus den großen Ebenen wuchsen am besten. Eine Auswahl an schnellwachsenden Herkünften könnte fünf Jahre nach der Pflanzung beginnen.

Resumen. Fueron establecidas fuentes de juníperos (Juniperus virginiana L.) como una prueba de derivación cerca de Colby, Kansas, U.S. en 1980. Se evaluaron altura, diámetro, número de tallos, densidad de copa, ángulo de andamiaje y vigor general con ANOVA, análisis de conglomerados, correlación simple y técnicas de análisis de regresión. Se encontraron claras diferencias entre fuente y conglomerados. La altura total en 23 años varió de 3.6 a $5.4 \mathrm{~m}$ (11.8 a 17.7 pies), el diámetro a la altura del pecho varió de 2.5 a $14.4 \mathrm{~cm}$ ( 1 a 5.7 pulg), y la tasa media de sobrevivencia fue $78 \%$. Las fuentes de las praderas centrales crecieron mejor. La selección de fuentes de rápido crecimiento puede empezar a los cinco años después de la plantación. 